\title{
Ingen kompromisvilje, men mere vold
}

\section{Aleksej Malasjenko}

\section{Efter Vladimir Putin kom til magten, blev enhver form for forhandling en umulighed. Det sidste, mislykkede forsøg på at få Moskva til at give ind- rømmelser var gidseltagningen i 2004 i Beslan}

Nordkaukasus er og bliver den mest ustabile region i Den Russiske Føderation. I løbet af de sidste 20 år har der her været fire krige - den første tjetjenske (1994-1996), den anden tjetjenske (1999-2002), den ossetiskingusjetiske konflikt (1992) og de tjetjenske separatisters indtrængen i Dagestan (1999).

I fire republikker - Tjetjenien, Dagestan, Ingusjetien og KabardinienBalkarien - opererer væbnede grupper fra den islamiske opposition.

Der findes ingen præcise opgørelser over antallet af militante i de enkelte republikker. Ifølge den øverstkommanderende for indenrigsministeriets styrker, armégeneral Nikolaj Rogosjkin, fører omkring 500 militante for tiden krig i Nordkaukasus. Den russiske viceindenrigsminister, general Arkadij Jedelev, antager, at der alene i Tjetjenien opererer 500 militante og i Ingusjetien 150. Ifølge oplysninger fra viceindenrigsministeren i Kabardinien-Balkarien, Naurbi Sjamborov, er der i hans republik 50 militante.

Paradoksalt nok er antallet af eksplosioner, mord og terroraktioner steget, efter at de føderale myndigheder i april 2009 afsluttede anti-terroroperationen i Tjetjenien. Nu er indflydelsesrige kaukasiske politikere blevet mål for angreb, heriblandt præsidenterne for Ingusjetien Junus-Bek Jevkurov, Tjetjenien Ramsan Kadyrov, og KabardinienBalkarien - Arsen Kanokov. I Dagestan, den folkerigeste republik i Nordkaukasus, føres der - som den kendte kaukasiske politiker Gadsji Makhatjev udtrykker det - en reel borgerkrig.

Den ustabile situation, den konstante konfrontation med de fødera- 
le myndigheder og det umulige i (den gensidige uvilje mod) at nå frem til et kompromis har bidraget til en radikalisering af oppositionsbevægelsen og fået dens deltagere til at ty til terroristiske kampmetoder. Under de tjetjenske krige har terroraktionerne - gidseltagninger, sprængninger af fly og eksplosioner i Moskva - haft som mål at få de føderale myndigheder til at indlede forhandlinger med separatisterne. Men efter at Vladimir Putin kom til magten, blev enhver form for forhandling en umulighed. Det sidste, mislykkede forsøg på at få Moskva til at give indrømmelser var gidseltagningen i 2004 i Beslan.

Efter Beslantragedien var der længe ingen terroraktioner uden for Nordkaukasus. Den første 'terroraktion udenfor' foregik efter en lang pause i Moskvas metro i marts 2010. Samtidig lød der eksplosioner i Tjetjenien og Dagestan. I maj i år (under 1. maj-festlighederne) var der endnu nogle terroraktioner, af hvilke den største var eksplosionen i Kabardinien-Balkariens hovedstad Naltjik på galopbanen, mens republikkens præsident Arsen Kanokov og andre af dens ledere befandt sig der.

Som årsager til terroraktionerne nævner de fleste eksperter den islamistiske oppositions hævn for udryddelsen af de fremtrædende oppositionelle Said Burjatskij, Ansor Astemirov og andre under Den Føderale Sikkerhedstjenestes (FSB's) og Indenrigsministeriets vellykkede operationer i årene 2009-2010. Oppositionens strategiske mål er antageligt at demonstrere sin egen styrke og prøve at vise det føderale center dets svaghed og manglende evne til at kontrollere situationen i regionen. Det er antageligt også et særligt svar på Moskvas forsøg på at foreslå en ny kurs i Nordkaukasus, der går ud på at gennemføre samfundsøkonomiske reformer i regionen og prøve at afstå fra udelukkende at løse Nordkaukasus' problemer med magt.

\section{Øget social indsats}

I slutningen af 2009 traf Moskva beslutning om at danne et nyt føderalt distrikt, Det Nordkaukasiske, og lægge seks af de syv sydlige republikker (minus Adygeja) og Stavropolregionen ind under det. Som præsidentens befuldmægtigede udsending i distriktet udnævntes den tidligere guvernør i Krasnojarsk-regionen, Aleksandr Khloponin, der anses for at være en særdeles succesrig leder, der har formået at løse den ugunstige økonomiske og sociale situation i Krasnojarsk-regionen. Udnævnelsen af ham betød, at Moskva havde besluttet at koncentrere opmærksomheden om de sociale og $ø$ konomiske problemer ud fra den antagelse, at man kun på den måde kan mindske den konstante politiske spænding.

Set med Moskvas øjne er en anden af Khloponins værdifulde egen- 
skaber den, at han ikke har forbindelser til de lokale klaner og interessegrupper, hvilket giver ham mulighed for at være uafhængig og opbygge sin egen selvstændige politik på grundlag af regionale og dermed fællesrussiske interesser. Som en velhavende mand (hans formue vurderes til 700 mio. USD) vil Khloponin desuden ikke blive inddraget $i$ korruptionsopgør.

Samtidig med udnævnelsen til præsidentens befuldmægtigede udsending i det nye distrikt fik Khloponin embedet som viceministerpræsident. Denne omstændighed vidner for det første om Nordkaukasus' særlige betydning for den russiske ledelse, og for det andet forudsætter en status som viceministerpræsident en bredest mulig kreds af politiske beføjelser og en mulighed for at gennemføre 'en ny kurs'.

Det skal erkendes, at dannelsen af et nyt føderalt distrikt i Nordkaukasus og udnævnelsen af en ny mand til dets leder faktisk indebar en indrømmelse af, at den hidtidige politik i regionen, der havde været ført i 10 år, havde spillet fallit.

Historisk og kulturelt set er Nordkaukasus ikke en homogen region. I dag ekstrapoleres dens forskelligartethed til den politiske situation. Nordkaukasus består af mindst to områder. Der er den i politisk og religiøs henseende urolige østlige sektor - Dagestan, Ingusjetien og Tjetjenien - der er den mindre problematiske centrale del - Kabardinien-
Balkarien og Nordossetien - og der er det relativt rolige vest - KaratjajTjerkessien og Adygej. Men den ustabilitet, der opstår i den østlige del af regionen, breder sig ud i alle retninger. Det gælder især Kabardinien-Balkarien, hvor spændingen er vokset siden 2005 .

Men der er problemer, der er fælles for hele den nordkaukasiske region. Det drejer sig først og fremmest om den tilbagestående økonomi og den totale finansielle afhængighed af Moskva. Alle republikker modtager bistand: I 2009 byggede Tjetjeniens og Ingusjetiens budgetter for 90 procents vedkommende på det føderale budget, Dagestans for 78 procents vedkommende, Karatjaj-Tjerkessiens for 67 procents vedkommende og Nordossetiens for 60 procents vedkommende.

\section{Penge i forkerte hænder}

Det er også uheldigt, at de penge, der bevilges fra den føderale kasse, ikke når ubeskåret frem til modtageren. En ikke ringe del 'klæber fast' til Moskva-embedsmændenes hænder som 'returkommission' (på russisk otkát, der er betegnelsen på et system, hvorved den embedsmand, der har ansvar for fordelingen af pengene, kræver en vis procent af det bevilgede beløb til sig selv).

Otkát kan udgøre over halvdelen af de bevilgede midler. I 2004 påstod den tjetjenske præsident Akhmed Kadyrov, at 80 pct. af de midler, der 
blev bevilget til genrejsningen af Tjetjenien, landede i Moskva-embedsmændenes lommer. Men selv hvis pengene når frem til republikken, anvendes de langt fra altid efter hensigten. Ofte er det republikkens eget bureaukrati, der efter forgodtbefindende i deres personlige interesse skalter og valter med dem. Den føderale kontrol med de lokale finanser er meget begrænset. $\mathrm{Og}$ forsøgene på at styrke den har foreløbig ikke givet positive resultater.

I republikkerne er der praktisk talt ikke nogen moderne økonomisk sektor tilbage. De virksomheder, der blev bygget i sovjettiden, er ødelagte eller forsømte. I Kabardinien-Balkarien er $\mathrm{fx}$ det gigantiske, nogle kilometer lange wolfram-molybdæn-kombinat $\mathrm{i}$ byen Tyrnaus helt sat ud af drift, i Tjetjenien har man ikke genopbygget det berømte raffinaderikompleks. Faglige færdigheder er gået tabt, størstedelen af specialisterne har forladt regionen af frygt for den kroniske ustabilitet eller simpelthen af frygt for deres liv. Eksperterne anvender nu ikke sjældent termen 'deindustrialisering' på Kaukasus.

Infrastrukturerne befinder sig i en forsømt tilstand. Dog ser Tjetjenien ud som en undtagelse; her er kvaliteten af vejene i Ramsan Kadyrovs regeringstid blevet betydeligt bedre end i naborepublikkerne.

$\varnothing$ konomien karakteriseres af ekstensivt landbrug, byggeri og handel. Byggeindustrien er orienteret mod lavt byggeri, mens der er klart for lidt byggeri af fleretageshuse. Undtagelsen er igen Tjetjenien, hvor det i de senere år er lykkedes at genopbygge Grosnij og andre af republikkens byer.

Nordkaukasus' tragedie er og bliver arbejdsløsheden, som er særlig stor blandt de unge. (I den største nordkaukasiske republik, Dagestan, er indbyggernes gennemsnitsalder 27-28 år.) Arbejdsløshedsprocenten i Ingusjetien er 57, i Tjetjenien 36,2. For Dagestan er arbejdsløsheden kun på 12,6 pct. Samtidig er de officielle tal for arbejdsløsheden sat for lavt. I Dagestan kommer den ifølge uofficielle kilder op på 30 pct., og $\mathrm{i}$ Tjetjenien er den over 50 pct.

\section{Unge havner i kriminalitet}

Spørgsmålet kan skildres endnu bredere: de unge lider ikke kun under arbejdsløshed, men generelt under manglen på fuldt udbyggede sociale, kulturelle og sportslige organer i regionen. De har ikke noget sted at gøre af sig selv hverken morgen eller aften. Det vækker irritation og bidrager til vækst i kriminaliteten.

Frustration er et generelt træk hos de fleste unge i regionen. På baggrund af det dårligt organiserede sociale og personlige liv tiltrækkes de unge mere og mere af oppositionen, som erklærer, at den kæmper for retfærdighed og en radikal ændring af livet på grundlag af islam. Som en kaukasisk kollega sagde til 
forfatteren af disse linjer, så "søger de unge op i bjergene (går over til oppositionen. Red.) af kedsomhed, og fordi de simpelthen ikke har noget at tage sig til."

Endnu et uløseligt problem er den kroniske, vanemæssige tilsidesættelse af den russiske føderale lovgivning. Det sker både dér, hvor myndighederne står stærkt, fx i Tjetjenien, hvor de ikke har brug for loven, og alt ordnes udelukkende, som præsident Ramsan Kadyrov vil have det, og dér, hvor myndighederne står svagere - i Ingusjetien og Dagestan, og de ikke kan tvinge deres borgere til at overholde loven. I Nordkaukasus gælder ofte 'konsensusreglen', ifølge hvilken denne eller hin politiske eller retslige beslutning træffes på grundlag af enighed mellem forskellige klaner og grupperinger. Som bekendt retter man sig langt fra altid efter lovene i det øvrige Rusland, men i Nordkaukasus ignoreres de fuldstændigt.

De politiske og samfundsmæssige institutioner - parlamenter og partier - er yderst svage. Parlamenterne er 'lommeparlamenter', dvs. i lommen på administrationen. Hvad angår partierne, heriblandt 'Forenet Rusland' (Vladimir Putins parti. Red.), så er deres virksomhed på den ene side helt underlagt den centrale ledelse, mens den på den anden side afhænger af de lokale funktionærer. I realiteten forsvarer partierne i Nordkaukasus etniske og andre gruppers og klaners interesser.

\section{Traditionernes renæssance}

Bagsiden af den ikke-virkende føderale lovgivning er bestræbelserne på i stadig større omfang at støtte sig til traditionelle institutioner, sædvaner og naturligvis til religionen. Nordkaukasus gennemgår en demoderniserings-etape (eller arkaiserings-etape). (I øvrigt kan omtrent det samme ses i de tidligere sovjetrepublikker i Centralasien). Resultaterne af traditionens 'renæssance' er tvetydige. På den ene side er de kaukasiske eliter mere trygge ved at arbejde under overholdelse af de traditionelle normer: det er nemmere at holde orden på den måde. På den anden side kan anvendelse af traditionen i nogle tilfælde skærpe de i forvejen konfliktfyldte situationer. Når den føderale straffelovgivning ikke virker, vinder blodhævn således udbredelse. Der kendes ikke så få tilfælde, hvor netop den har været det vigtigste argument for, at politibetjente er blevet 'straffet' af slægtninge til dem, der på deres side har lidt under magtorganernes repræsentanter.

Ingusjetiens præsident, Junus-Bek Jevkurov, opfordrer til at genskabe systemet af taiper (en slags klaner), som efter hans mening vil kunne normalisere forholdene i samfundet. I Tjetjenien har man genoplivet wyrd-systemet, de 'små' muslimske broderskaber. I Dagestan har man bevaret systemet med at fordele stillinger i staten efter etniske kvoter. 
Uregelmæssigheder i dette system tages meget ilde op i samfundet.

Retraditionaliseringen af samfundsforholdene møder forståelse hos nogle russiske eksperter. Således mener præsidenten for Akademiet for Politisk Videnskab, Oleg Sjabrov, at netop i Kaukasus "er civilsamfundets institutioner traditionelt udviklede", og at netop de er i stand til at mindske spændingen i regionens republikker.

I den østlige del af regionen vinder reislamiseringen frem. Anvendelsen af islam som regulator af de sociale forhold forekommer lovmæssig. Under den permanente ustabilitet er bestræbelserne for at finde et sikkert alternativ til indretningen af staten og samfundet fuldt forståelige. Ønsket om 'at leve ifølge sharia', når andre love ikke virker, høres i de mest forskellige befolkningslag. Det er umuligt præcist at angive, hvilken procentdel af indbyggerne i hver enkelt republik der går ind for en islamisering. Ifølge mine personlige iagttagelser deler omtrent halvdelen af muslimerne i Dagestan ideen om at støtte sig til islam. Det er betegnende, at der er mange unge blandt tilhængerne af en islamisering.

\section{Islamiseringens fremmarch}

En islamisering støttes også af de regeringsloyale tilhængere af de islamiske religiøst-juridiske skoler, mazkhaberne (den shafiitiske og den khanafitiske), af medlemmerne af sufi-tarikaterne og naturligvis de islamiske oppositionelle, der i den russiske presse kaldes wahhabiter og salafiter. Mellem tilhængerne af de forskellige religiøse retninger er der fortsat uoverensstemmelser og endda fjendskab.

Samtidig går den indre-islamiske polemik kun ud på, hvordan man så effektivt som muligt kan genindføre sharia. I den kontekst er der to holdninger. Den ene, den yderliggående, er repræsenteret af tilhængere af dannelsen af en islamisk stat i Nordkaukasus efter regionens udtræden (ved en jihad) af Den Russiske Føderation, mens tilhængerne af den anden mener, at 'sharia-territoriet', dvs. det territorium, hvor de grundlæggende islamiske normer vil være gældende, kan skabes inden for rammerne af Den Russiske Føderation.

Den radikale opposition går ind for skabelsen af en separat, uafhængig islamisk stat i Nordkaukasus Det Kaukasiske Emirat - hvilket allerede blev annonceret i 2007. Den tidligere leder af den separatistiske Tjetjenske Republik Itjkerija, Doku Umarov, har udnævnt sig selv til emir over dette virtuelle produkt. Dermed har han omorienteret den islamiske opposition fra kampen for Tjetjeniens uafhængighed til dannelsen af en nordkaukasisk islamisk stat.

Islamiseringen støttes af visse verdslige politikere, mest af Ramsan Kadyrov, som prøver at udnytte islam som instrument til at konsoli- 
dere det tjetjenske samfund og styrke sit eget regime. Under Kadyrov er islam ved at blive en af de legitime faktorer i Den Tjetjenske Republiks politiske liv. "De verdslige myndigheder ser på islams grundlæggende principper og værdier og understreger dermed deres konfessionelle identitet", hed det i resolutionen fra seminaret 'Islam i Tjetjenien: historie og samtid', som blev afholdt i Tjetjenien i juni 2008. Den verdslige magt er de facto personificeret i Ramsan selv.

Tjetjeniens præsident kræver af folk en streng overholdelse af sharianormerne for opførsel og vil have, at kvinderne går i tilsvarende tøj først og fremmest med hovedtørklæder, og han giver præmier til kvindelige studerende, der går med disse tørklæder. Han støtter polygami, indfører begrænsninger for (visse steder forbud mod) forbrug og salg af alkohol og for spillevirksomhed. Der er gang i byggeriet af moskeer, hvis antal i Tjetjenien allerede overstiger 400. I 2007 åbnede i Grosnij den største moske i Rusland og Europa (med plads til 10.000 andagtssøgende). I 2009 gav Kadyrov ordre til fjerne mindesmærket for sin fader i Grosnij, fordi det ifølge islamiske forskrifter er forbudt at afbilde mennesker.

I regionen drages der et stadig tydeligere skel mellem dem, som støtter en bevarelse af statens verdslige karakter, og dem, som mener, at religion ikke kan adskilles fra politik, heller ikke fra statens politik. Forkæmpere for, at staten er verdslig, har svært ved at bede Moskva om hjælp. For det første nyder 'det verdslige center' ikke større tillid hos den lokale befolkning. For det andet vil Moskva ikke risikere at fordømme islamiseringsideen, som støttes af politikere og repræsentanter for gejstligheden, som er loyale over for centralmagten.

I en vis forstand optræder Moskva ganske pragmatisk. På den anden side dannes der til gengæld i Sydrusland en etno-religiøs enklave, som bestræber sig på at leve i overensstemmelse med sine egne traditionelle normer, herunder sharia.

\section{Udvikler sig baglæns}

Samfundet er umærkeligt ved at udvikle sig baglæns. Det begrænser endnu mere administrationen af Nordkaukasus fra Moskva og gør gradvis regionen til såkaldt 'nært udland'.

I de sidste tyve år er man i Nordkaukasus blevet forvisset om, at Centret ikke har nogen rationel politik i regionen. Undertiden fremføres den opfattelse, at politikerne i Moskva bevidst støtter den spændte situation i regionen for at gøre det lettere selv at kontrollere regionen. I den forbindelse sættes der ikke spørgsmålstegn ved fællesskabet med Rusland.

Den tjetjenske separatisme var en undtagelse, og den pris, tjetjenerne 
betalte for den, var utilstedelig høj. Den overvejende stemning i det kaukasiske samfund kan kort formuleres på følgende måde: "Vi går ind for at være en del af Rusland, men vi er utilfredse med Moskva." I regionen er man overbevist om, at netop Moskva fremprovokerede de tjetjenske krige og dermed fik hele Nordkaukasus til at styrte sammen, og derfor er Centret forpligtet til at betale 'en særlig regning' herfor, med andre ord bevilge endnu flere midler til at bringe orden i Nordkaukasus.

Den russisk-georgiske krig i 2008 og Ruslands anerkendelse af Abkhasiens og Sydossetiens selvstændighed har afspejlet sig på flere måder i situationen i Nordkaukasus. Rusland demonstrerede selvfølgelig magt, men separatistregionernes pludselige omdannelse til nationalstater vakte en del undren i Nordkaukasus. Indbyggerne spurgte sig selv, hvorfor Rusland var i stand til at løse sine akutte problemer i forholdet til Georgien så operativt, mens det $\mathrm{i}$ årevis har forsømt at regulere de indre grænsespørgsmål mellem Dagestan og Tjetjenien, Tjetjenien og Ingusjetien samt Ingusjetien og Nordossetien.

Hvorfor fandt Moskva straks penge til at yde bistand til to nyfødte stater og endog til at betale fjerntliggende lande (Nicaragua og Nauru) for at anerkende dem?

I det nordkaukasiske samfund mærkes der skuffelse og træthed over den permanente krise, der for længst er blevet en systemkrise, og over den uvisse fremtid. Derfor skal Centret ikke alene udarbejde langfristede programmer, men om muligt også træffe beslutninger, der kan neutralisere de spontane konfliktsituationer, der opstår hele tiden i næsten hver eneste republik og mellem republikkerne. Dette så meget desto mere som 'små konflikter' let kan blive store.

\section{Pisk og gulerod}

Hvis Moskva virkelig vil gøre sin kurs i Nordkaukasus mere effektiv, så skal man finde en optimal kombination af pisk og gulerod, dvs. afholde sig fra den sædvanligvis foretrukne anvendelse af voldsmetoder. Efter terroraktionen i Moskvas metro i marts 2010, efter de yderligere terroraktioner, der fandt sted i Kaukasus næsten samtidig hermed i marts-maj 2010, synes Centrets mening om anvendelse af voldsmetoder som tidligere at være uvis.

På den ene side sagde præsident Dmitrij Medvedev, da han på et møde i Makhatjkala med lederne af de kaukasiske republikker overvejede, hvordan metoderne til bekæmpelse af terrorisme kunne forbedres, at terroristerne skal rammes af 'dolkestød', der ikke berører den øvrige fredelige befolkning. På den anden side 'udvidede' han to dage senere på et møde med medlemmer af Statsdumaen kredsen af terrorister 
til at omfatte dem, som "koger suppe til dem eller vasker deres tøj". Det vil sige, at kategorien af terrorister bliver suppleret med deres familiemedlemmer, hvilket uundgåeligt vil føre til en udvidelse af den personkreds, der vil blive udsat for forfølgelser fra magtorganernes side.

Som følge heraf bevares spændingen i samfundet og dets manglende accept af såvel føderale som lokale myndigheders handlinger. Det er klart, at det er yderst vanskeligt at gennemføre antiterroraktioner og i det hele taget bekæmpe en radikal opposition i et traditionelt samfund, hvor modstanderen let kan finde støtte hos sin familie og slægt. Her er det umuligt at udarbejde en absolut og fejlfri taktik. Men hvis myndighederne vil opnå forsoning med samfundet, skal de i hvert fald optræde mere forsigtigt og forholde sig forskelligt til deltagerne i protestbevægelsen og ikke kvalificere dem udelukkende som 'banditter'. I denne forbindelse er det på sin plads at minde om, at krigen i Tjetjenien (1994-96) blev afsluttet netop på grundlag af et kompromis mellem Moskva og de tidligere separatister.

\section{Arbejdsdeling}

Foreløbig er der ved at ske en slags arbejdsdeling mellem Kremls nye mand Khloponin og repræsentanterne for magtorganerne. Præsidentens befuldmægtigede repræsentant skal udelukkende beskæftige sig med fredelige, dvs. økonomiske og sociale problemer. Repræsentanterne for magtorganerne skal sikre en $\mathrm{i}$ hvert fald relativ stabilitet.

Da Aleksandr Khloponin havde tiltrådt sin stilling, definerede han fire 'clusters' for Nordkaukasus som de vigtigste: turisme, landbrug, energi og uddannelse. Mens forbedringen af energisituationen hovedsageligt har at gøre med indførelse af favorable elafgifter for Det Nordkaukasiske Distrikt, og landbruget skal reformeres grundigt og alsidigt, så skal uddannelse og turistindustri faktisk skabes fra bunden af. Og det er der foreløbig ikke de nødvendige finansielle midler eller relevant personale til.

Khloponin regner med at tiltrække midler fra de nordkaukasiske oligarker, der hidtil har undgået at investere penge i en så ustabil region. I dette spørgsmål håber han klart på støtte fra den russiske regering, der vil kunne give forretningsfolkene uofficielle garantier om støtte til deres investeringer. To forretningsmænd, Mikhail Gutserijev og Telman Ismailov, har allerede reageret (eller er blevet tvunget til at reagere) på forslaget om at deltage i Kaukasus' genrejsning.

Hvordan man skal løse problemet med manglen på kvalificeret personale er i det hele taget uvist. Den forhenværende præsident for Ingusjetien, Murad Sjasikov, og Ramsan Kadyrov har gjort forsøg på at overtale bare en lille del af den russiske 


\section{TEMA: NORDKAUKASUS}

befolkning, der har forladt Kaukasus, til at vende tilbage, men forgæves.

\section{Fælles kaukasisk marked}

Endnu en retning i Khloponins virke er dannelsen af 'et fælles kaukasisk marked'. Denne ide har længe ligget i luften, men der er praktisk talt ingen horisontale forbindelser mellem republikkerne, og indtil for nylig er der ikke kommet forslag om at etablere sådanne. Forberedelserne til vinterolympiaden i Sotji kan muligvis i et vist omfang bidrage til dannelsen af et fælleskaukasisk marked.

Hvor effektive Khloponins handlinger og dermed Moskvas nye kurs i regionen vil vise sig at være, bliver klart i den allernærmeste fremtid. Præsidentens befuldmægtigede re- præsentant indrømmer selv, at "han ikke kender et eneste menneske i verden, som nu kan tilbyde en opskrift på, hvordan man skal bære sig $\mathrm{ad}$, for at alt pludseligt bliver godt $\mathrm{i}$ Kaukasus”. I det nordkaukasiske samfund er der i dag en forventning om positive forandringer. Hvis de ikke bliver til noget, og alt forbliver ved det gamle, så kan regionen i bedste fald forvente en fortsættelse af stagnationen, en fortsat forværring af folks liv samt en ustabilitet, der indebærer sociale og politiske omvæltninger.

Aleksej Malasjenko er specialist $i$ Nordkaukasus og forsker i regionen ved Carnegie Center i Moskva.

(Oversat fra russisk af Lars P. PoulsenHansen) 